\title{
Differentials in the epidemiological profile of canine visceral leishmaniasis in the semi-arid region of Paraíba, Brazil ${ }^{1}$
}

\author{
Raizza B.S. Silva ${ }^{2 *}$ (D) Laysa F. Franco-Silva², Diana A. Lima ${ }^{3}$, Saul S. Fonseca ${ }^{3}$, \\ Marília A.S. Ferreira ${ }^{4}$, Rafael C. Silva ${ }^{5}$, Milena A.A. Lira ${ }^{6}$ and Marcia A. Melo ${ }^{2 *}$
}

\begin{abstract}
Silva R.B.S., Franco-Silva L.F., Lima D.A., Fonseca S.S., Ferreira M.A.S., Silva R.C., Lira M.A.A. \& Melo M.A. 2021. Differentials in the epidemiological profile of canine visceral leishmaniasis in the semi-arid region of Paraíba, Brazil. Pesquisa Veterinária Brasileira 41:e06773, 2021. Universidade Federal de Campina Grande, Campus Patos, Av. Universitária s/n, Santa Cecília, Patos, PB 58708-110, Brazil. E-mail: raizzabss@hotmail.com

The objective of this study was to estimate the prevalence of canine visceral leishmaniasis (CVL) and to identify the differences in associated factors to its occurrence in urban area and countrysides in the municipality of Santa Luzia located in the semi-arid region of Paraíba. In the years 2015 and 2016, 779 blood samples from dogs were collected. The prevalence was determined by three serological techniques, ELISA-S7 ${ }^{\circledR}$ Kit, DPP ${ }^{\circledR}$ Rapid Test and EIE-LVC ${ }^{\circledR}$ Kit, considering positive the samples that reacted in at least two assays. Associated factors were determined by univariate and multivariate analyzes of the guardians' responses to the epidemiological questionnaire. The prevalence of anti-Leishmania infantum antibodies in the studied municipality was $15.00 \%(117 / 779)$, being higher in the urban area $(15.20 \%)$ than in the countryside $(13.60 \%)$. The neighborhood with the highest prevalence was Frei Damião with $26.40 \%$ (33/125), being considered a hotspot (OR 1.245, $p=0.007)$. Other associated factors were the semi-domiciliary breeding (OR 1.798, $p=0.025$ ), in the urban area, and hunting $\operatorname{dog}(\mathrm{OR} 18.505, p=0.016)$, contact with cattle (OR 17.298, $p=0.022$ ) and environment where the dog is raised (OR 4.802, $p=0.024$ ) in the countryside. In the municipality of Santa Luzia, the prevalence of canine visceral leishmaniasis is high and the disease is widely distributed. Epidemiological differences between urban area and the countryside could be observed demonstrating the need for more adequate control measures for each locality and proving the urbanization process.
\end{abstract}

INDEX TERMS: Canine visceral leishmaniasis, epidemiological profile, Leishmania infantum, neglected diseases, prevalence, associated factors, semi-arid region, zoonoses, Brazil.

RESUMO.- [Diferenciais no perfil epidemiológico da leishmaniose visceral canina no semiárido da Paraíba, Brasil.] 0 objetivo desta pesquisa foi estimar a prevalência da leishmaniose visceral canina (LVC) e identificar as diferenças nos fatores relacionados à sua ocorrência nas zonas urbana

\footnotetext{
${ }^{1}$ Received on August 13, 2021.

Accepted for publication on August 30, 2021.

${ }^{2}$ Graduate Program in Science and Animal Health (PPGCSA), Universidade Federal de Campina Grande (UFCG), Campus Patos, Av. Universitária s/n, Santa Cecília, Patos, PB 58708-110, Brazil. E-mails: raizzabss@hotmail.com, laysafrfranco@gmail.com, marcia.melo@ufcg.edu.br; *Corresponding author: raizzabss@hotmail.com, marcia.melo@ufcg.edu.br

${ }^{3}$ Undergraduate Course in Veterinary Medicine, Universidade Federal de Campina Grande (UFCG), Campus Patos, Av. Universitária s/n, Santa Cecília, Patos, PB 58708-110, Brasil.E-mails: dianalimamv@gmail.com, saul_123ssf@hotmail.com
}

e rural do município de Santa Luzia, localizado no semiárido paraibano. Nos anos de 2015 e 2016, coletaram-se 779 amostras de sangue de cães. A prevalência foi determinada através de três técnicas sorológicas, Kit ELISA-S7 ${ }^{\circledR}$, teste rápido DPP $^{\circledR}$ e Kit EIE-LVC ${ }^{\circledR}$, considerando positivas as amostras que

\footnotetext{
${ }^{4}$ Graduate Program in Biological Sciences, Universidade Federal de Pernambuco (UFPE), Av. Moraes Rego 1235, Cidade Universitária, Recife, PE 50670-901, Brazil. E-mail: marilia_andresa@hotmail.com

${ }^{5}$ Undergraduate Course in Biological Sciences, Universidade Federal de Campina Grande (UFCG), Campus de Patos, Av. Universitária s/n, Santa Cecília, Patos, PB 58708-110, Brazil. E-mail: rafael.cosme34@gmail.com

${ }^{6}$ Veterinarian of Health Surveillance, Secretaria de Saúde de Santa Luzia, Santa Luzia, PB 58600-000, Brazil. E-mail: aquilavet@yahoo.com.br
} 
reagiram em, pelo menos, dois ensaios. Os fatores relacionados foram determinados por meio das análises estatísticas uni e multivariada das respostas dos tutores ao questionário epidemiológico. A prevalência de anticorpos anti-Leishmania infantum encontrada no município estudado foi de 15,00\% $(117 / 779)$, sendo maior na zona urbana $(15,20 \%)$ do que na rural (13,60\%). 0 bairro que apresentou maior prevalência foi o Frei Damião com 26,40\% (33/125), sendo considerado um hotspot (OR 1,245; $p=0,007$ ). Outros fatores relacionados encontrados foram a criação semidomiciliar (OR 1,798; $p=0,025)$, na zorna urbana, e cão de caça (OR 18,505; $p=0,016$ ), contato com bovinos (OR 17,298; $p=0,022$ ) e ambiente onde o cão é criado (OR 4,802; $p=0,024$ ), na zona rural. Verifica-se a elevada prevalência da leishmaniose visceral canina e a sua ampla distribuição no município de Santa Luzia. Diferenças epidemiológicas entre as zonas urbana e rural puderam ser observadas, demonstrando a necessidade de medidas de controle mais adequadas para cada localidade e comprovando o processo de urbanização.

TERMOS DE INDEXAÇÃO: Leishmaniose visceral canina, perfil epidemiológico, Leishmania infantum, doenças negligenciadas, prevalência, fatores relacionados, região semiárida, zoonoses, Brasil.

\section{INTRODUCTION}

Visceral leishmaniasis (VL) is a neglected tropical disease, of zoonotic nature, caused by the protozoan Leishmania infantum (sin. L. chagasi), which affects the mononuclear phagocyte system of humans, canids and other mammals (WHO 2010).

The VL is transmitted by phlebotomine insects and the main transmitter species in Brazil is Lutzomyia longipalpis. This zoonosis has a broad worldwide distribution occurring in Asia, Europe, Middle East, Africa and in the Americas (Brasil 2014). In the year of 2015, 15.00\% (3456) of the world's new cases of VL occurred in the Americas, and Brazil was responsible for $3336(96.50 \%)$ of these cases (WHO 2017a), with only one Units of the Federation, Acre, without any registers of autochthonous cases of VL from 2007 to 2019, according to data of the Sinan Net (Brasil 2020).

In Brazil, visceral leishmaniasis has been expanding and urbanizing since the 1980 's. These phenomena are related to the conditions in which the dogs and their guardians live (disorganized occupations and precarious living conditions), the migration of human beings and their pets, climate changes and deforestation, in addition to the dispersion and urbanization of the vector (WHO 2002, Costa 2008, Salomón et al. 2015).

The control strategies of the VL in Brazil, according to the "Programa de Vigilância e Controle da Leishmaniose Visceral" (PVCLV - Visceral Leishmaniasis Surveillance and Control Program), are based on the early diagnosis and treatment of the human cases, on the control of the vectors with the use of insecticides and in the detection of infected dogs, by serological analysis, with subsequent euthanasia of the positive animals (Brasil 2014), since the dog is considered the main reservoir of the disease in endemic urban areas. For the diagnosis of the canine visceral leishmaniosis (CVL), the "Ministério da Saúde" (Ministry of Health) recommends the use of DPP ${ }^{\circledR}$ rapid test (Bio-Manguinhos), for screening, and the EIE-LVC ${ }^{\circledR}$ (Bio-Manguinhos) as confirmatory test (Brasil 2011).

In 2016, the first drug for the treatment of the CVL was registered in the "Ministério da Agricultura, Pecuária e
Abastecimento" (MAPA - Ministry of Agriculture, Livestock and Food Supply) and in 2017 started to be commercialized in Brazil. However, it is not indicated as a public health measure for the control of the disease (Brasil 2016). According to the Interministerial Ordinance no. 1.426, of 11th July 2008, the treatment of CVL with products of human use or not registered in the MAPA is still prohibited. This decision of the "Ministério da Saúde" and the MAPA has as main fundaments: the possibility of dogs in treatment remaining as reservoirs and sources of infection for the vector, and the existence of risk of selection of strains resistant to the drugs available for the treatment of leishmaniasis in humans (Brasil 2008).

In Paraíba, in 2015, the incidence of human VL was of 1.2 cases per 100,000 inhabitants (Brasil 2020). In April of the same year, in the municipality of Santa Luzia/PB, the death of a five-year old child due to visceral leishmaniasis, resident in the São Sebastião neighborhood, was registered. According to the Health Surveillance Agency of the Santa Luzia Municipal Government, after the identification of this autochthonous case, actions recommended by the "Ministério da Saúde" were conducted in the vicinity of the human case (São Sebastião and Nossa Senhora de Fátima neighborhoods), such as: entomological investigation, spraying with insecticides, environmental sanitation, canine serological survey, and euthanasia of the reagent dogs. Due to the lack of knowledge of CVL in other areas of the municipality, the objective of the study was to estimate the prevalence of the disease in the municipality of Santa Luzia to identify possible associated factors, so that measures for the control and prevention of new cases could be taken.

\section{MATERIALS AND METHODS}

The cross-sectional study was conducted in the urban area and countrysides of Santa Luzia ( $06^{\circ} 52^{\prime}$ S and $\left.36^{\circ} 55^{\prime} \mathrm{W}\right)$, a municipality of the semi-arid region of the State of Paraíba (Fig.1), with an area of $455 \mathrm{~km}^{2}$. In 2016, the estimated population was 15,341 inhabitants, with more than $90 \%$ residing in the urban area, according to the "Instituto Brasileiro de Geografia e Estatística" (IBGE - Brazilian Institute of Geography and Statistics). Considering the existence of one dog for every seven inhabitants, the estimated canine population was of 2,191 animals. The number of animals used was determined

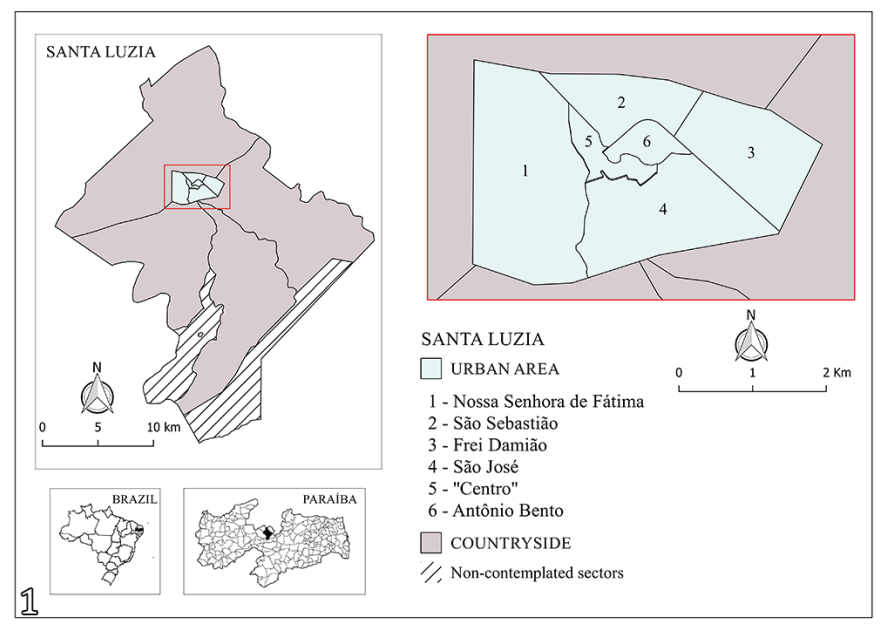

Fig.1. Location map of the municipality of Santa Luzia/PB, Brazil, categorized by areas. 
by the calculation formula for simple random samples, as proposed by Thrusfield (2007), considering an expected prevalence of 50\%, $99 \%$ confidence level and sampling error of $4 \%$. The minimum estimated number of animals was of 706, but as a security measure, an additional $10 \%$ was added to the sample number.

The survey was carried out from July 2015 to July 2016 in dogs over six months of age and without distinction of breed or gender.

In the urban area, sampling was carried out for convenience at a collection point in each neighborhood after wide dissemination on local radio and by Endemic Control Agents (ECA) and Health Agents (HA). The sampling in the countryside was by conglomerates and the collection was carried out in 16 rural communities by random raffle, being contemplated all the houses and all the dogs of the raffled localities.

The blood was obtained by jugular vein or cephalic vein venipuncture, with the aid of $5 \mathrm{~mL}$ syringes and sterile $25 \times 8 \mathrm{~mm}$ needles of individual use. A total of $5 \mathrm{~mL}$ of blood was immediately deposited in a tube containing $4 \%$ sodium citrate. After collection, the material was sent to the "Laboratório de Biologia Molecular do Semiárido" of the "Universidade Federal de Campina Grande" (LBMSA-UFCG), University Campus in the municipality of Patos/ PB. The samples were centrifuged at 2000 rotation per minute (rpm), for 5 minutes, for the separation of the plasma, which was stored in $1.5 \mathrm{~mL}$ microtubes, identified and stored at $-20^{\circ} \mathrm{C}$ until the serological assays were performed.

The serological tests used for the diagnosis of the CVL were: ELISA-S7 ${ }^{\circledR}$ Kit (Biogene Ind. e Com. Ltda) performed by the team of the LBMSA-UFCG; DPP ${ }^{\circledR}$ (Bio-Manguinhos) Rapid Test, carried out by the Endemic Disease Control Agents of the Health Department of Santa Luzia; and as recommended by the "Ministério da Saúde", only positive samples in $\mathrm{DPP}^{\circledR}$ were tested by immunoenzymatic assay (EIE-LVC ${ }^{\circledR}$ Kit, Bio-Manguinhos) at the "Laboratório Central de Saúde Pública" (LACEN - Central Public Health Laboratory) in the state of Paraíba. All the assays were conducted according to the protocols proposed by the manufacturers. The animal was considered positive when it reacted in two serological tests.

The dog guardians answered an epidemiological questionnaire to identify the socio-environmental conditions that act as possible associated factors for the disease. The analysis of the factors associated to the seropositivity was carried out in two stages: univariate and multivariate analysis. The independent variables were categorized and codified and those which presented a $p$-value of $\leq 0.20$ by the chi-square test or Fisher's exact test (Zar 1999) were used in the multivariate analysis by multiple logistic regression (Hosmer \& Lemesho 2000). The level of significance adopted in the multiple analysis was of $5 \%$. The analysis was carried out with the IBM SPSS Statistics Base 22.0 software.

The work was approved by the Ethics Committee of the Health and Rural Technology Center (CSTR), of the UFCG, under the protocol no. $283 / 2015$.

\section{RESULTS}

Of the 779 blood samples collected from dogs in the municipality of Santa Luzia for the serological survey, 676 were from dogs in the urban area, and 103 from the countryside. Considering as positive the dogs that reacted in at least two serologies, the CVL seroprevalence in the municipality of Santa Luzia was 15.02\% (117/779, 95\% CI 12.51-17.53\%), of which 103 positive dogs were from urban areas and 14 from countryside, resulting in prevalence of $15.24 \%$ (103/676, 95\% CI 12.53-17.95\%) and $13.59 \%(14 / 103,95 \%$ CI 6.97-20.21\%), respectively.
There was no significant difference in the positivity of the dogs from both areas $(p=0.774)$.

Most of the guardians of the seropositive dogs had a family income of less than two minimum salaries (63.47\%). It was possible to observe that as the economic status of the family increases, lower is the prevalence of CVL. In relation to the canine population with visceral leishmaniasis, 61.54\% (72/117) were male, $25.64 \%$ (30/117) were aged between two to four years, $74.36 \%$ (87/117) were mongrels, without significant difference between the categories of these variables ( $p>0.05)$.

Most guardians raise dogs in a semi-household manner $(68.29 \%, 532 / 779)$, that is, the animal is loose on the street at certain times of the day, among them, 83.76\% (98/117) were positive. The contact of the dogs with other animals, such as other dogs, cats, equine, ruminants, birds and/or wild animals was reported by $67.27 \%$ (524/779) of the guardians; $71.79 \%$ (84/117) of the positive dogs maintained some contact with other animals, among these stood out other dogs $(n=60)$, birds $(n=30)$ and cats $(n=26)$. The cleaning of the outside pet area was performed by $90.50 \%$ (705/779) of the guardians, but the frequency of this cleaning varied from daily to monthly; the prevalence of CVL increased with the increase in the period without cleaning. Only $7.70 \%$ of the dogs (60/779) had used an insecticide-impregnated collar and none of the dogs had been vaccinated against CVL; at the time of collection, no animals were wearing this type of collar.

The analysis of the associated factors was carried out to determine the differences between the urban area and countryside, the results obtained are expressed in the Table 1 and 2 . The associated factor of the urban area were the type of rearing (semi-household manner), and the neighborhood (Frei Damião) was considered a hotspot. Regarding the canine population with VL and resident in the Frei Damião neighborhood, it was observed that $90.00 \%$ of them were raised in a semi-domicile regime and all positive dogs had their place of residence cleaned monthly; $75.80 \%$ of the responsible for these dogs had a family income of less than two minimum wages. The associated factors for the countryside were hunting dogs, contact with bovine and keep the dog in the backyard partially covered with concrete and partially with soil.

\section{DISCUSSION}

The prevalence of canine infection is an important risk indicator for the occurrence of human VL (Oliveira et al. 2008, Araújo et al. 2013, Teixeira-Neto et al. 2014) and its rates can vary widely among Brazilian municipalities, with values between $0.17 \%$ in São José do Rio Preto, São Paulo (Da Nardo et al. 2011), to 75.30\% in Anastácio, Mato Grosso do Sul (Cortada et al. 2004). The discrepancy between these values is a consequence of the characteristics of the region and the population studied, and the diagnostic methods used in each survey. Prevalence like those obtained in Santa Luzia were observed in municipalities with similar physiographic and socioeconomic characteristics, such as in Petrolina, Pernambuco (Pimentel et al. 2015), and in municipalities in the semi-arid region of Paraíba (Fernandes et al. 2016, Silva et al. 2016, Silva et al. 2018), making clear the influence of socio-environmental factors on the prevalence of the disease (Rondon et al. 2008, Dantas-Torres 2009, Ursine et al. 2016). 
Table 1. Univariate analysis of the factors associated to the seropositivity to canine visceral leishmaniasis in the urban and rural areas of Santa Luzia, Paraíba, from 2015 to 2016

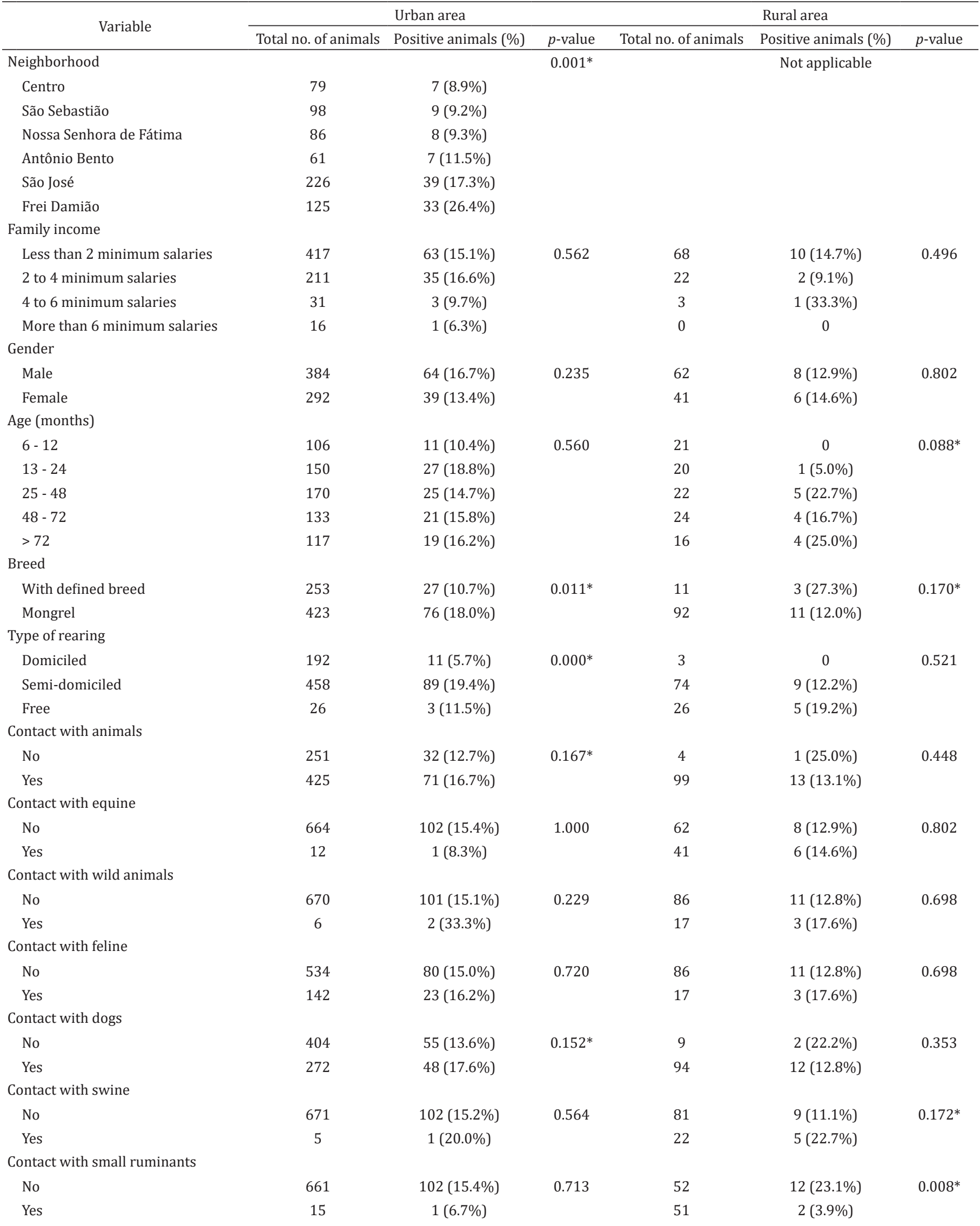


Contact with bovine

No 671

Yes

Contact with birds

No

Yes

Environment where is reared

Soil

Cement

Soil and cement

Cleaning of the outside pet area

No

Yes

Frequency of the cleaning

Daily

Weekly

Fortnightly

Monthly

Presence of ticks

No 106

Yes

Always lived in Santa Luzia

No

Yes

Adopted

No

From the streets

From another owner

Hunting dog

No

Yes

Place used for sleeping

Indoors

Peri-domiciliar

In the street

How the dog spends the night

Free

Tied-up

Made use of repellent collar

No

Yes

* Variables used in the multiple logistic regression.
671
5

529

147

288

271

117

18

658

478

159

10

11

570

78

598

19

179

470

616

60

135

526

15

460

216

618

58

$$
102(15.2 \%)
$$$$
1 \text { (20.0\%) }
$$

0.564

83 (15.7\%)

0.534

20 (13.6\%)

50 (17.4\%)

0.270

34 (12.5\%)

19 (16.2\%)

3 (16.7\%)

$100(15.2 \%)$

0.746

59 (12.3\%)

35 (22.0\%)

3 (30.0\%)

3 (27.3\%)

17 (16.0\%)

86 (15.1\%)

0.803

7 (9.0\%)

$0.102 *$

96 (16.1\%)

$6(31.6 \%)$

$29(16.2 \%)$

68 (14.5\%)

$0,122^{*}$

92 (14.9\%)

11 (18.3\%)

0.484

16 (11.9\%)

86 (16.3\%)

$1(6.7 \%)$

66 (14.3\%)

37 (17.1\%)

0.348

97 (15.7\%)

$6(10.3 \%)$

$0.020^{*}$

0.279

0.278
46

57

3 (6.5\%)

11 (19.3\%)

$4(16.7 \%)$

$10(12.7 \%)$

$12(12.4 \%)$

$0.197 *$

0

2 (40.0\%)

10 (17.9\%)

4 (8.5\%)

0

1 (3.4\%)

3 (23.1\%)

0

2 (10.0\%)

1.000

12 (14.5\%)

0

1.000

$14(14.4 \%)$

$3(8.3 \%)$

0.205

7 (22.6\%)

4 (11.1\%)

9 (10.3\%)

5 (31.3\%)

0

14 \%)

100

-

8 (17.4\%)

0.312

57

6 (10.5\%)

101

2

$14(13.9 \%)$

1.000

0

$0.025 *$

1.000

Table 2. Associated factors for canine visceral leishmaniasis per areas of the municipality of Santa Luzia, Paraíba, estimated by multiple logistic regression, from 2015 to 2016

\begin{tabular}{|c|c|c|c|c|}
\hline Area & Associated factors & Odds ratio & CI 95\% ${ }^{\mathrm{a}}$ & p-value \\
\hline Urban & Type of rearing (Semi-domiciled) & 1.80 & $1.08-3.01$ & 0.025 \\
\hline \multirow[t]{2}{*}{ Rural } & Hunting dog (Yes) & 18.51 & $1.71-200.35$ & 0.016 \\
\hline & Environment where the dog is reared (Soil and cement) & 4.80 & $1.23-18.76$ & 0.024 \\
\hline
\end{tabular}

${ }^{a} \mathrm{CI} 95 \%$ = confidence interval of $95 \%$. 
CVL is generally more prevalent in rural areas than in urban areas (Amóra et al. 2006, Almeida et al. 2012). However, in some regions changes in this pattern occurred, with the expansion of the disease to urban areas (França-Silva et al. 2003, Guimarães et al. 2017), which was also observed in the present study. This urbanization process has occurred since the 1980s and is associated with several phenomena such as the migration of humans and their pets from the countryside to the urban area (associated with disorderly occupation and precarious living conditions), climate change and deforestation, in addition to the dispersion and adaptation of the vector (WHO 2002, Costa 2008, Salomón et al. 2015). In Santa Luzia, the peripheral neighborhoods grow in a disorganized way, as is the case of the Frei Damião neighborhood, a hotspot that features remnant areas of Caatinga (Fig.2-3). Araujo et al. (2016) found that the presence of a green area near the residence behaves as a risk factor for CVL in Petrolina/PE, Northeastern Brazil. In addition to the presence of forest, there are areas with deforestation (Fig.2-3), further favoring the contact of wild and vector reservoirs with people and dogs. In addition, the presence of shrubs, weeds and the accumulation of organic matter is frequent in backyards and in vacant lots close to homes. These environmental changes caused by humans generate an increase in the amount of decomposing organic matter that, associated with the precariousness of sanitary conditions, favors the sandfly life cycle, and contributes to the expansion of the disease (Aversi-Ferreira et al. 2014, Teles et al. 2015). In fact, the influence of anthropic actions on the epidemiology of VL has been reported in studies carried out in the Northeast region of Brazil. Cerbino Neto et al. (2009), in a study on human VL in Teresina/PI, and Cesse et al. (2001), in the city of Petrolina/PE, observed a higher occurrence of the disease in peripheral areas of the cities with rapid and recent urban occupation, demonstrating the presence of VL associated to environmental changes due to the anthropic action.

Associated with environmental conditions, most of the dog guardians in the Frei Damião neighborhood had an income of less than two minimum salaries and, according to the World Health Organization (WHO 2017b), leishmaniasis is strongly associated to the lack of financial resources, being known as a disease which affects low-income populations. In Belo Horizonte, Southeast Brazil, human VL was correlated with low family income (Araújo et al. 2013), and this characteristic was even pointed out as an associated factor for the occurrence of canine disease (Coura-Vital et al. 2011).

The highest proportion of positive dogs in the Frei Damião neighborhood $(26.40 \%)$ in relation to the São Sebastião neighborhood (9.18\%) was probably due to the canine survey and the euthanasia of positive dogs rallied shortly after the occurrence of the case as recommended by the PVCLV. The canine survey was also carried out in the Nossa Senhora de Fátima neighborhood (9.30\%), and a cohort study was indicated to ascertain the incidence and real risk of becoming ill due to visceral leishmaniasis in the neighborhoods of Santa Luzia.

Another associated factor to urban area was the breeding of dogs on a semi-domestic basis, in which dogs roam freely on the street for part of the day. This is a common practice in the region, where guardians let their dogs loose all day, locking them up only at night around the premises of the house. Most guardians release the dogs in the late afternoon and early evening, a period of milder weather, but which corresponds to the greater activity of the vector Lutzomyia longipalpis, which presents twilight and nocturnal habits (Brasil 2014). Fernandes et al. (2016) and Costa et al. (2018) also found this association, and Belo et al. (2013) observed that the chances of acquiring Leishmania sp. it is lower in strictly domestic animals. Veloso et al. (2021) indicate that some peridomestic characteristics, such as the absence of barriers that allow dogs free access to the street, can contribute to the maintenance of the infection cycle in urban areas.

In the rural area, the dog's permanence in spaces with areas containing both natural soil and waterproofed with cement was identified as an associated factor, a result also found by Fernandes et al. (2016). Raising animals in these conditions can make it difficult to clean the area and favor the accumulation of organic matter, which promotes an ideal habitat for the oviposition and proliferation of the vector. Garbage can also attract synanthropic animals, such as rodents, which have already been identified as possible
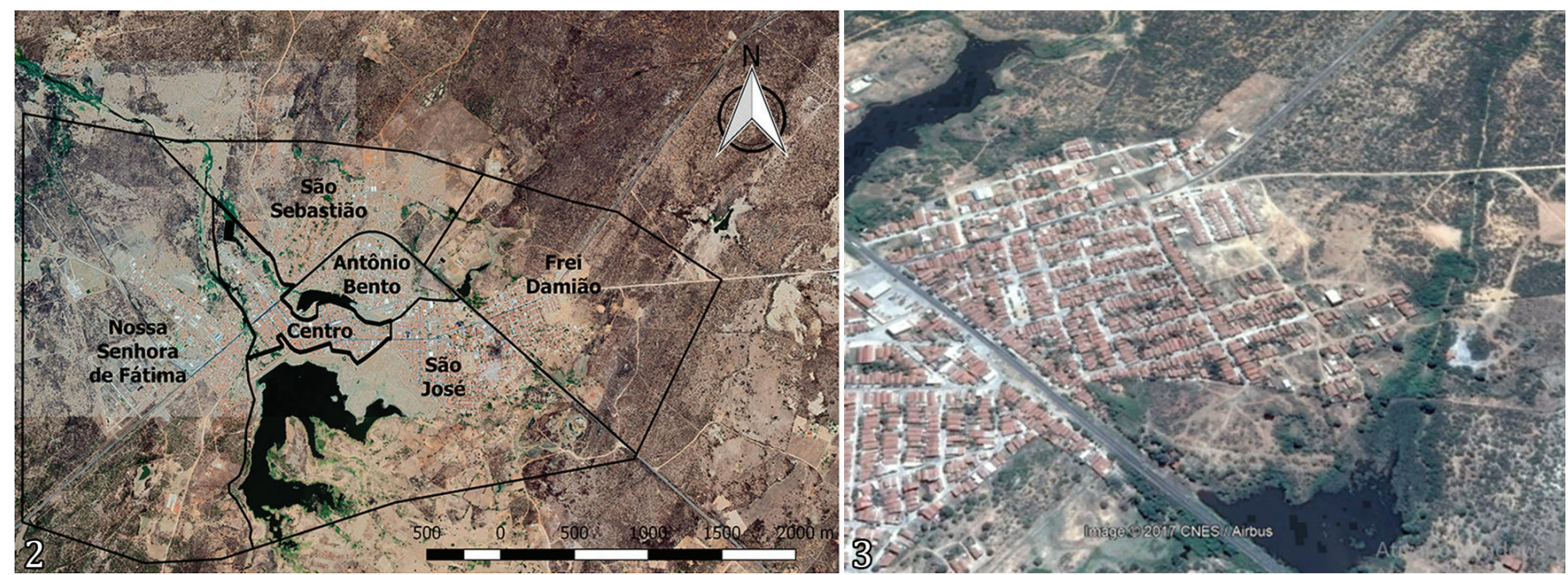

Fig.2-3. (2) Satellite image of the municipality of Santa Luzia, with the limitation of the neighborhoods. (3) Highlight of the Frei Damião neighborhood. Source: adapted from the Google Earth. 
reservoirs (Lainson \& Rangel 2005), thereby establishing the conditions for maintaining the domestic VL cycle.

According to Dantas-Torres (2009), the lifestyle of the animals is an important associated factor for CVL. Several studies have already shown that habit-related factors, such as guard function and the free access to the streets or exterior of the house, are factors associated to the risk of canine infection, as these expose the animals to a greater contact with the vector (Amóra et al. 2006, Almeida et al. 2012). In this context, the hunting activity may also expose the animals to a greater risk of infection, what happened in the countryside. This activity, common in the Northeast of Brazil, usually occurs at night, being another factor that favors contact with the vector. Maziero et al. (2014) observed in Santa Catarina, South of Brazil, a greater positivity among Pampas Deerhound, a Brazilian breed of hunting dog, suggesting that these animals would be more susceptible to the vector, due to the hunting activity in woods and forests. According to Rondon et al. (2008), regions with abundant vegetation favor the development and proliferation of the vector, facilitating canine infection.

Another associated factor for canine infection in countryside was the contact with cattle, which may be related to the presence of the feces of these animals since the sandfly females lay eggs in moist soil rich in organic matter (Troncarelli et al. 2012). Cattle have been associated with leishmaniasis in several other studies, being identified as one of the preferred food sources of L. longipalpis in an endemic area of Colombia (Morrison et al. 1993). In addition, the use of insecticides against ectoparasites in this species may favor the transfer of the feeding of sandflies to humans and dogs, increasing the risk of infection (Kolaczinski et al. 2008, Bern et al. 2010). On the other hand, the importance of the bovine species has been controversial, being associated with an increased risk in some studies and decreased in others, warning about the complexity of the effect of cattle breeding in regions endemic for leishmaniasis (Bern et al. 2010).

\section{CONCLUSIONS}

The urbanization of visceral leishmaniasis (VL) occurs in the municipality of Santa Luzia, with epidemiological differences between the urban and rural areas.

Control and prevention measures must be prioritized based on the associated factors identified in each area, maximizing the efficiency of the program, and minimizing the chance of new cases.

Acknowledgments.- We are grateful to the "Coordenação de Aperfeiçoamento de Pessoal de Nível Superior" (CAPES), the "Conselho Nacional de Desenvolvimento Científico e Tecnológico" (CNPq) for the concession of scholarships and to the Santa Luzia/PB Municipal Government.

Conflict of interest statement.- The authors do not have conflicting interests.

\section{REFERENCES}

Almeida A.B.P.F., Sousa V.R.F., Cruz F.A.C.S., Dahroug M.A.A., Figueiredo F.B. \& Madeira M.F. 2012. Canine visceral leishmaniasis: seroprevalence and risk factors in Cuiabá, Mato Grosso, Brazil. Revta Bras. Parasitol. Vet. 21(4):359365. <https://dx.doi.org/10.1590/S1984-29612012005000005>

Amóra S.S.A., Santos M.J.P., Alves N.D., Costa S.C.G., Calabrese K.S., Monteiro A.J. \& Rocha M.F.G. 2006. Fatores relacionados com a positividade de cães para leishmaniose visceral em área endêmica do Estado do Rio Grande do Norte, Brasil. Ciência Rural. 36(6):1854-1859. <https://dx.doi.org/10.1590/ S0103-84782006000600029>

Araujo A.C., Costa A.P., Silva I.W.G., Matos N.N.V.G., Dantas A.C.S., Ferreira F., Marcili A. \& Horta M.C. 2016. Epidemiological aspects and risk factors for infection by Leishmania infantum chagasi in dogs from municipality of Petrolina, Northeastern Brazil. Vet. Parasitol., Reg. Stud. Rep. 3-4:41-48. <https://dx.doi.org/10.1016/j.vprsr.2016.07.001><PMid:31014498>

Araújo V.E.M., Pinheiro L.C., Almeida M.C.M., Menezes F.C., Morais M.H.F., Reis I.A., Assunção R.M. \& Carneiro M. 2013 Relative risk of visceral leishmaniasis in Brazil: a spatial analysis in urban area. PLoS Negl. Trop. Dis. 7(11):e2540. <https://dx.doi.org/10.1371/journal.pntd.0002540> <PMid:24244776>

Aversi-Ferreira R.A.G.M.F., Galvão J.D., Silva S.F., Cavalcante G.F., Silva E.V., Bhatia-Dey N. \& Aversi-Ferreira T.A. 2014. Geographical and Environmental Variables of Leishmaniasis Transmission. Leishmaniasis, Trends in Epidemiology, Diagnosis and Treatment, Intech Open. p.106-124. <https:// dx.doi.org/10.5772/57546>

Belo V.S., Struchinera C.J., Wernecka G.L., Barbosa D.S., Oliveira R.B., Teixeira Neto R.G. \& Silva E.S. 2013. A systematic review and meta-analysis of the factors associated with Leishmania infantum infection in dogs in Brazil. Vet. Parasitol. 195(1/2):1-13. <https://dx.doi.org/10.1016/j. vetpar.2013.03.010 > <Mid:23561325>

Bern C., Courtenay 0.\& Alvar J. 2010. Of cattle, sand flies and men: a systematic review of risk factor analyses for South Asian visceral leishmaniasis and implications for elimination. PLoS Negl. Trop. Dis. 4(2):e599. <https://dx.doi.org/10.1371/journal.pntd.0000599><PMid:20161727>

Brasil 2008. Proíbe o tratamento de leishmaniose visceral canina com produtos de uso humano ou não registrados no Ministério da Agricultura, Pecuária e Abastecimento. Portaria Interministerial no 1.426, de 11 de julho de 2008, Ministério da Saúde, Ministério da Agricultura, Pecuária e Abastecimento, Brasília, DF. 2p.

Brasil 2011. Esclarecimentos sobre substituição do protocolo diagnóstico da leishmaniose visceral canina (LVC). Nota Técnica Conjunta ํㅡ 1, Coordenação Geral de Doenças Transmissíveis, Coordenação Geral de Laboratórios de Saúde Pública, Departamento de Vigilância das Doenças Transmissíveis, Secretaria de Vigilância em Saúde, Ministério da Saúde, Brasília, DF. 3p.

Brasil 2014. Manual de Vigilância e Controle da Leishmaniose Visceral. Ministério da Saúde, Brasília, DF. 120p.

Brasil 2016. Nota Técnica Conjunta no 001/2016 MAPA/MS. Ministério da Agricultura, Pecuária e Abastecimento, Ministério da Saúde, Brasília, DF. 2p.

Brasil 2020. Portal da Saúde SUS (Sinan/SVS/MS). Ministério da Saúde, Brasília, DF. Available at <http://tabnet.datasus.gov.br/cgi/deftohtm. exe?sinannet/cnv/leishvbr.def > Accessed on 30 Dez. 2020.

Cerbino Neto J., Werneck G.L. \& Costa CHN. 2009. Factors associated with the incidence of urban visceral leishmaniasis: an ecological study in Teresina, Piauí state, Brazil. Cad. Saúde Públ. 25(7):1543-1551. <https://dx.doi. org/10.1590/S0102-311X2009000700012>

Cesse E.A.P., Carvalho E.F., Andrade P.P., Ramalho W.M. \& Luna L. 2001. Organização do espaço urbano e expansão do calazar. Revta Bras. Saúde Matern. Infant. 1(2):167-176. <https://dx.doi.org/10.1590/S151938292001000200010>

Cortada V.M., Doval M.E., Lima M.A.A.S., Oshiro E.T., Meneses C.R., Abreu-Silva A.L., Cupolilo E., Souza C.S.F., Cardoso F.O., Valle T.Z., Brasil R.P., Calabrese K.S. \& Costa S.C.G. 2004. Canine visceral leishmaniosis in Anastácio, Mato Grosso do Sul state, Brazil. Vet. Res. Commun. 28(5):365-374. <https:// dx.doi.org/10.1023/b:verc.0000035014.80785.b7> <PMid:15379431>

Costa C.H.N. 2008. Characterization and speculations on the urbanization of visceral leishmaniasis in Brazil. Cad. Saúde Públ. 24(12):2959-2963. <https://dx.doi.org/10.1590/S0102-311X2008001200027> 
Costa D.N.C.C., Blangiardo M., Rodas L.A.C., Nunes C.M., Hiramoto R.M., Tolezano J.E., Bonfietti L.X., Bermudi P.M.M., Cipriano R.S., Cardoso G.C.D., Codeço C.T. \& Chiaravalloti-Neto F. 2018. Canine visceral leishmaniasis in Araçatuba, state of São Paulo, Brazil, and its relationship with characteristics of dogs and their owners: a cross-sectional and spatial analysis using a geostatistical approach. BMC Vet Res. 14(1):229. <https://dx.doi.org/10.1186/s12917018-1550-9><PMid:30124171>

Coura-Vital W., Marques M.J., Veloso V.M., Roatt B.M., Aguiar-Soares R.D.O., Reis L.E., Braga S.L., Morais M.H., Reis A.B. \& Carneiro M. 2011. Prevalence and factors associated with Leishmania infantum infection of dogs from an urban area of Brazil as identified by molecular methods. PLoS Negl. Trop. Dis. 5(8):e1291. <https://dx.doi.org/10.1371/journal.pntd.0001291> $<$ PMid:21858243>

Da Nardo C.D.D., Rossi C.N., Laurenti M.D. \& Marcondes M. 2011. Detecção de anticorpos anti-Leishmania infantum syn chagasi em cães de São José do Rio Preto, São Paulo. Braz. J. Vet. Res. Anim. Sci. 48(5):425-428.

Dantas-Torres F. 2009. Canine leishmaniosis in South America. Parasit. Vectors 2(Supl.1):1-8. <https://dx.doi.org/10.1186/1756-3305-2-S1-S1> $<$ PMid:19426440>

Fernandes A.R.F., Pimenta C.L.R.M., Vidal I.F., Oliveira G.C., Sartori R.S., Araújo R.B., Melo M.A., Langoni H. \& Azevedo S.S. 2016. Risk factors associated with seropositivity for Leishmania spp. and Trypanosoma cruzi in dogs in the state of Paraiba, Brazil. Revta. Bras. Parasitol. Vet. 25(1):90-98. <https://dx.doi.org/10.1590/S1984-29612016010><PMid:26982555>

França-Silva J.C., Costa R.T., Siqueira A.M., Machado-Coelho G.L.L., Costa C.A., Mayrink W., Vieira E.P., Costa J.S., Genaro O. \& Nascimento E. 2003. Epidemiolgy of canine visceral leishmaniasis in the endemic área of Montes Claros Municipality, Minas Gerais state, Brazil. Vet. Parasitol. 111(2/3):161-173. <https://dx.doi.org/10.1016/s0304-4017(02)00351-5> $<$ PMid:12531292>

Guimarães A., Raimundo J.M., Santos H.D., Machado R.Z. \& Baldani C.D. 2017. Serosurvey for canine visceral leishmaniasis in rural and urban areas of the Brazilian Legal Amazon. Braz. J. Infect. Dis. 21(2):207-208. <https:// dx.doi.org/10.1016/j.bjid.2016.10.013>

Hosmer D.W. \& Lemesho W.S. 2000. Applied Logistic Regression. 2nd ed. John Wiley and Sons, New York. 375p. Available at <http://books.google.com.br/ books?id=Po0RLQ7USIMC \&printsec $=$ frontcover\&hl=pt-BR\&source $=$ gbs ge_summary_r\&cad $=0 \# v=$ onepage \&q\&f=-false $>$ Accessed on Oct. 2015.

Kolaczinski J.H., Reithinger R., Worku D.T., Ocheng A., Kasimiro J., Kabatereine N. \& Brooker S. 2008. Risk factors of visceral leishmaniasis in East Africa: a case-control study in Pokot territory of Kenya and Uganda. Int. J. Epidemiol. 37(2):344-352. <https://dx.doi.org/10.1093/ije/dym275> <PMid:18184669>

Lainson R. \& Rangel E. 2005. Lutzomyia longipalpis and the ecoepidemiology of American visceral leishmaniasis, with particular reference to Brazil - a review. Mem. Inst. Oswaldo Cruz 100(8):811-827. <https://dx.doi org/10.1590/S0074-02762005000800001>

Maziero N., Thomaz-Soccol V., Steindel M., Link J.S., Rossini D., Alban S.M. \& Nascimento A.J. 2014. Rural-urban focus of canine visceral leishmaniosis in the far western region of Santa Catarina State, Brazil. Vet. Parasitol. 205(1):92-95. <https://dx.doi.org/10.1016/j.vetpar.2014.06.005> $<$ PMid:25023635>

Morrison A.C., Ferro C. \& Tesh R.B. 1993. Hostpreferences of the sand fly Lutzomyia longipalpis atan endemic focus of American visceral leishmaniasis in Colombia. Am. J. Trop. Med. Hyg. 49(1):68-75. <https:// dx.doi.org/10.4269/ajtmh.1993.49.68> <PMid:8352394>

Oliveira C.D.L., Morais M.H.F. \& Machado-Coelho G.L.L. 2008. Visceral leishmaniasis in large Brazilian cities: challenges for control. Cad. Saúde Públ. 24(12):2953-2958. <https://dx.doi.org/10.1590/s0102311x2008001200026><PMid:19082288>
Pimentel D.S., Ramos R.A.N., Santana M.A., Maia C.S., Carvalho G.A., Silva H.P. \& Alves L.C. 2015. Prevalence of zoonotic visceral leishmaniasis in dogs in an endemic area of Brazil. Revta Soc. Bras. Med. Trop. 48(4):491-493. <https://dx.doi.org/10.1590/0037-8682-0224-2014>

Rondon F.C.M., Bevilaqua C.M., Franke C.R., Barros R.S., Oliveira F.R., Alcântara A.C. \& Diniz A.T. 2008. Cross-sectional serological study of canine Leishmania infection in Fortaleza, Ceará state, Brazil. Vet. Parasitol. 155(1/2):24-31. <https://dx.doi.org/10.1016/j.vetpar.2008.04.014><PMid:18565676>

Salomón O.D., Feliciangeli M.D., Quintana M.G., Afonso M.M. \& Rangel E.F. 2015. Lutzomyia longipalpis urbanisation and control. Mem. Inst. Oswaldo Cruz 110(7):831-846. <https://dx.doi.org/10.1590/0074-02760150207>

Silva R.B.S., Mendes R.S., Santana V.L., Souza H.C., Ramos C.P.S., Souza A.P., Andrade P.P. \& Melo M.A. 2016. Aspectos epidemiológicos da leishmaniose visceral canina na zona rural do semiárido paraibano e análise de técnicas de diagnóstico. Pesq. Vet. Bras. 36(7):625-629. <https://dx.doi.org/10.1590/ S0100-736X2016000700011>

Silva R.B.S., Porto M.L., Barbosa W.O., Souza H.C., Marques N.F.D.S.P., Azevedo S.S., Andrade P.P. \& Melo M.A. 2018. Seroprevalence and risk factors associated with canine visceral leishmaniasis in the State of Paraíba, Brazil. Revta Soc. Bras. Med. Trop. 51(5):683-688. <https://dx.doi.org/10.1590/00378682-0429-2017><PMid:30304279>

Teixeira-Neto R.G., Silva E.S., Nascimento R.A., Belo V.S., Oliveira C.D.L., Pinheiro L.C. \& Gontijo C.M.F. 2014. Canine visceral leishmaniasis in an urban setting of Southeastern Brazil: an ecological study involving spatial analysis. Parasit. Vectors 7:485. <https://dx.doi.org/10.1186/s13071014-0485-7><PMid:25326767>

Teles A.P.S., Herrera H.M., Ayres F.M., Brazuna J.C.M. \& de Abreu U.G.P. 2015. Fatores de risco associados à ocorrência da leishmaniose visceral na área urbana do município de Campo Grande/MS. Hygeia. 11(21):35-48.

Thrusfield M. 2007. Veterinary Epidemiology. Wiley Blackwell, Oxford. 610p.

Troncarelli M.Z., Carneiro D.M.V.F. \& Langoni H. 2012. Visceral Leishmaniosis: An Old Disease with Continuous Impact on Public Health. Zoonosis, Intech Open, p.263-282. <https://dx.doi.org/10.5772/38680>

Ursine R.L., Dias J.V.L., Morais H.A. \& Pires H.H.R. 2016. Human and canine visceral leishmaniasis in an emerging focus in Araçuaí, Minas Gerais: spatial distribution and socio-environmental factors. Mem Ins. Oswaldo Cruz 111(8):505-511. <https://dx.doi.org/10.1590/0074-02760160133>

Veloso E.C.M., Negreiros A.S., Silva J.P., Moura L.D., Nascimento L.F.M., Silva T.S., Werneck G.L. \& Cruz M.S.P.E. 2021. Socio-economic and environmental factors associated with the occurrence of canine infection by Leishmania infantum in Teresina, Brazil. Vet. Parasitol. Reg. Stud. Rep. 24:e100561. <https://dx.doi.org/10.1016/j.vprsr.2021.100561> <PMid:34024377>

WHO 2002. Urbanization: an increasing risk factor for leishmaniasis. Wkly. Epidemiol. Rec. 77(44):365-370. <PMid:12428426>. Available at <http:// www.who.int/wer> Accessed on Oct. 20, 2017.

WHO 2010. Control of the leishmaniasis. World Health Organization, Geneva. Available at <https://apps.who.int/iris/bitstream/handle/10665/44412/ WHO_TRS_949_eng.pdf?sequence $=1 \&$ amp;isAllowed $=y>$ Accessed on Nov. 13, 2017.

WHO 2017a. Global leishmaniasis update, 2006-2015: a turning point in leishmaniasis surveillance. Wkly. Epidemiol. Rec. 92:(38):557-565. <PMid:28945057> Available at <http://apps.who.int/iris/bitstream/10665/258974/1/ WER9238-557-565.pdf> Accessed on Oct. 20, 2017.

WHO 2017b. Leishmaniasis. World Health Organization, Geneva. Available at <http://www.who.int/mediacentre/factsheets/fs375/en/> Accessed on Oct. 20, 2017.

Zar J.H. 1999. Biostatistical Analysis. 4th ed. Prentice-Hall, New Jersey. 663p. 